\title{
Recombination Repair
}

National Cancer Institute

\section{Source}

National Cancer Institute. Recombination Repair. NCI Thesaurus. Code C19534.

Homologous recombination can operate at both double-strand breaks and free ends.

The homologous chromosome serves as a template for DNA repair during recombination. 